\title{
AYURLOG
}

National Journal of Research in Ayurved Science

A peer-reviewed open access Indexed e-journal of Ayurved

\section{"Study of Physico-chemical properties of herbs which are useful in blood related health problems."}

\author{
P. U. Shinde* ${ }^{1}$, B. A. Patange ${ }^{2}$
}

1. B.A.M.S., M.D. (RASASHASTRA),

2. Associate Professor,

Shalya Tantra Department, Ayurvedic Mahavidhyalay, Pusad, Maharashtra.

*Corresponding author: patangebhausaheb@gmail.com

\section{Abstract:}

Every plant is beneficial to us and has medicinal effect. We will first discuss about blood i.ie. blood is most precious content of human body and its content are RBCS ,WBCS and platelets. Impure blood may causes various disease like acne allergies skin rashes stomatitius psoriasis ,fever and so on. So there is need of external as well as internal a use of medication. The herbs taken haridra, guduchi and amalki plays most important role in blood purifiction i.e. Raktaprasadana and Nutritious values in them. Study of organoleptic and physicochemical properties are important to check the identity and purity of drugs. these properties helps to take more effective drug in remedied. emblica officinalis, physico-chemical properties, analytical tests etc
Keywords: emblica officinalis, haridra, guduchi, amalki, Blood related disease

\section{INTRODUCTION:}

Traditionally the herbs guduchi, haridra, amalki are used to treat huge variety of health problems. these herbs are most important medicines .plants are used in medicines of ayurveda because of having a number of pharmacological as vell as therapeutic properties. these herbs recommnded regular nutrtrional therapy and has antioxident activity. this study includes steps from selection o f herbs of good quality and study of its anlytical studies for identity, purity, sttrength of herbs.it helps to take select herbs for preparations of more effective remedies for skin diseases due to impure blood. study involves raw materials were selected by applying tests as per standards given in 
ayurvedic pharmacopia and granthas.

\section{AIMS AND OBJECTIVES:}

1. Study of physico-chemical properties of herbs haridra, amalki, guduchi.

2. To provide simple and effective remedies for raktaprasadna i.e. blood purification.

\section{MATERIALS AND METHODS:}

The present study includes steps as

1.raw material selection 2.analyical study and observations

1.raw materials : herbs are guduchi ,haridra and amalki .

Samples of herbs were procured from 3 different places from these which fulfills all grahya lakshnas mentioned in samhitas. Samples were subjected to organolreptic and analytical tests to get Genuine samples. Samples herbs were procured fro local market. Authenticity of materials was confirmed by experts respective fields. their originality and purity was identified and selected as per standard mentioned in in ayurvedic pharamacopia of India.

1.Guduchi:

Latin name: Tinospora cordifolai linn.

Family: Minispemaaciae

Used part:stem

Active Principle: berberin, Gliloin, tinosporarin, starch

Lengthy stems were twisted, swelling nat node show a little brown surface marked with warty protuberncnce due to circular lenticles.

2.Haridsra:Latin name:Curcuma longa linn.

Family: Zingiberaceae

Used part: kand-rhizome

Active principal: curcumin. Vit A, protein, carbohydrate.

Some rhizomes of haridra were long and some of round in shape. it has charasttristics and resinous odour. it was bitter and aromatic taste.

\section{Amalki:}

Latin name: Emblica officinalis

Family:Euphorbiacea e

Used part: Fruit

Active principle :Vit C, Gallic acids, tannic acid, glucose

Dried fruit of amalki consists of cured pieces of pericarpe of dried fruit and bulk colour -grey to black .pieces showing a broad, highly shrivel led and wrinkled external convex surface to somewhat concave. External surface shows a few whitish specks. it was amla and kashaya in taste.

2.Analytical study: Data collected through the study was analyzed and observations, results were noted down.

Analytical tests of herbal drugs:

Identification of samples: 


\begin{tabular}{|l|l|l|}
\hline Samples & Part used & Identified as \\
\hline Haridra & Rhizome-tuber & Curcuma longa linn. \\
\hline Guduchi & Root,stem & Tinospora cordifolia wild \\
\hline Amalki & Fruit(dried) & Emblica officinallis Gaerth \\
\hline
\end{tabular}

\begin{tabular}{|l|l|l|l|l|}
\hline Herbs & Total ash & $\begin{array}{l}\text { Acid insoluble } \\
\text { ash }\end{array}$ & $\begin{array}{l}\text { Water insoluble } \\
\text { extract }\end{array}$ & $\begin{array}{l}\text { Alcohol soluble } \\
\text { extract }\end{array}$ \\
\hline Haridra & $6.06 \%$ & $0.26 \%$ & $17.29 \%$ & $10.20 \%$ \\
\hline Guduchi & $7.92 \%$ & $1.075 \%$ & $20.22 \%$ & $5.45 \%$ \\
\hline Amalki & $3.119 \%$ & $1.38 \%$ & $53.28 \%$ & $4.88 \%$ \\
\hline
\end{tabular}

Organoleptic examinations:

\begin{tabular}{|l|l|l|l|l|l|}
\hline HERBS & $\begin{array}{l}\text { Shabda } \\
\text { (sound) }\end{array}$ & $\begin{array}{l}\text { Sparsha } \\
\text { (TOUCH) }\end{array}$ & $\begin{array}{l}\text { Roop } \\
\text { (Appearance) }\end{array}$ & $\begin{array}{l}\text { Rasa } \\
\text { (taste) }\end{array}$ & $\begin{array}{l}\text { Gandha } \\
\text { (Smell) }\end{array}$ \\
\hline Haridra & Non-specific & Slight hard & Yellow & Tikta, katu & Characteristic \\
\hline Guduchi & Non-specific & Slight hard & Faint green & Tikta & None \\
\hline Amalki & Non-specific & Slight hard & Brownish & $\begin{array}{l}\text { Amla, } \\
\text { Kashay }\end{array}$ & None \\
\hline
\end{tabular}

\section{Discussion:}

The present study entitled was selected to provide more effective remedies containing herbs- Guduchi, Haridra, Amalki with the help of analytical study. These are very useful herbs in blood related diseases. the present study can be equated in accordance with pharmacopial standard of india and British pharmacopoiae. Study was carried out on basis of ayurvedic panchbhautik and analytical physic chemical properties.
Then observations and results were made from these data collected noted here.This study helps for identity, purity and strength of herbs.

Herbs have many homeostastic (equilibrium) actions on human body but we discuss their main actions as:

1. $\mathrm{HB}$ activator $-\mathrm{it}$ increases $\mathrm{Hb} \%$ in blood which is needful in daily actions that hers are Guduchi, amalki and these are helpful in diseases like anaemia, jaundice etc. 
2. Herbs which decreases heat in blood are amalki, guduchi and helpful in hyperacidity, peptic ulcer etc.

3. Haemostatic action i.e. clotting factor increases hat herbs are haidra, amalki.

4. Reduces increased viscosity of blood that herbs are haridra, guduchi.

5. Cardio-tonic i.e.it increases cardiac muscle tone that herbs are haridra, guduchi.

6. these herbs have antibiotic activity useful in infectious diseases i.e. guduchi is antihelminthic and haridra is antibacterial.

7. Digestive capacity increases and has nutritive actions that herbs are amalki, guduchi and haridra.

Amalki is profoundly witnessed as vyasthapna and recommended to be incorrated in regular nutritional therapy..It consists of 2 hydrolysablic, tannins of less molecular weight called emblicannina and B. Tannins, pedunclagin and punigluconino displkay heavy antioxidant activity.

Haridra act as antibiotic, antitoxic and complexion promoter anti oxidant activity guduchi clinically acts as medhya, antimalerial and anti leprotic actions are possessed by root of plans. Glycosides , alkallloids, steroids phenolics are major chemical constituents of plants antioxidant.

\section{CONCLUSIONS:}

From above discussion traditionally these herbs are very useful to treat huge variety of health problems. So as per their various actions they helps to purify the blood. thus herbs are effective in acne, anaemia, skin diseases etc. They are easily available each drug individually effective in blood disorder so used in many remedies. but for more effectiveness and and to get total better effect of herbs they should be original and should have better quality. it means herbs should be pure and in original form. for this analytical criteria and physicochemical properties are very important to study its purify and strenghth. using these criteria we can get standard quality of drug. So better effective remedies containing these herbs can be prepared for blood related health problems.

\section{References-}

1. Charak samhita of agnivesha, pt. Kashinath shastri, edited by Dr. Gangasahay pandeya, part2,Varanasi: Chaukhamba Sanskrit Sansthahn, Reprint:2006;p.28

2. Vaidya Ravidatta Shastri,Harit samhita, Chaukhamba Sanskrit 
series office, Vranasi.

3. Shri bhavmishra ,bhavvprakash chikitsa,Comm. PROFF k.c. chunekar,edited with Vidyotini hindi commentary $\quad 10 / 16$ Chaukhambhabhartiacadamy,Vara naasi,123.
4. Pharmacopia of india,part 2,the controller of publication,Delhi, $1^{\text {st }}$ edition.

5. www.enwikipedia.org

6. www.himalayadrugs.com

7. www.zanduayurveda.com

\section{Cite this article:}

"Study of Physico-chemical properties of herbs which are useful in blood related health problems."

P.U. Shinde, B. A. Patange

Ayurlog: National Journal of Research in Ayurved Science-2020; (8) (1): 1 - 5 